ECPS Organisation Profile Series \#2 


\section{Boogaloo Bois: Violent Anti-Establishment Extremists in Festive Hawaiian Shirts BY BULENT KENES}

\section{ABSTRACT}

As a pro-Second Amendment movement, the Boogaloo Boys are easily recognizable because of their Hawaiian-themed Aloha shirts and masks along with their semiautomatic weapons. Having the basic characteristics of anti-establishment far-right populists and seeing the outbreak of violence as something like a party, typically accelerationist Boogaloo Boys use these Hawaiian shirts to hide their intention to trigger a civil war to overthrow what they regard as a corrupt establishment in the US.

BULENT KENES is an academic and a journalist who has over 25 years of professional experience. He has managed multiple publications, both in Turkish and English.

ECPS Leader Profile Series offer analyses of political leaders and prominent public figures with populist tendencies. Unless otherwise indicated, the views expressed by the author are only attributable him and not to any institution with which they are associated.

The profile available for free downloading from the ECPS website (www. populismstudies.org)

(C)ECPS 2021 


\section{Table of contents}

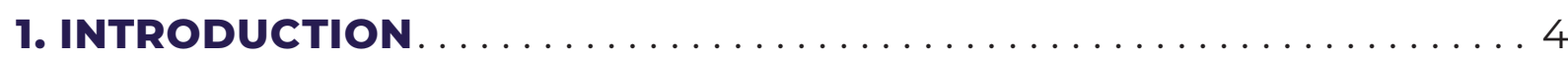

2. NO LONGER ABOUT MUSIC AND DANCE, BUT ABOUT MENACE . . 6

3. INSPIRED BY "THE TURNER DIARIES"

4. ACCELERATIONIST BOOGALOOERS INFILTRATE PROTESTS AS A TACTIC

5. SOME BOOGALOO BOYS ARE EXPLICIT WHITE NATIONALISTS AND NEO-NAZIS

6. WORKING-CLASS AND LOW-INCOME GROUPS FORM THE CORE

7. SOCIAL MEDIA (FACEBOOK): BOOGALOOERS' FERTILE HABITAT

8. 4CHAN BIRTHED BOOGALOOERS, FACEBOOK HELPED TO GROW

9. VIOLENCE: BOOGALOOERS TARGET POLICE AS MOST ACCESSIBLE SYMBOL OF GOVERNMENT 


\section{INTRODUCTION}

Through 2021, white supremacists and far-right extremists will remain the most "persistent and lethal threat" in the United States (US), where political and ideological divisions fall cleanly along racial lines (Newkirk II, 2019) according to a document prepared by the US Department of Homeland Security in 2020. However, former US President Donald Trump regularly downplayed this threat during his term (Sands, 2020). Many experts already associate rising far-right extremism with the rise of Trump. Hate crimes, anti-Semitism, and the number of hate groups have risen sharply since Trump's campaign began in 2015. The Tech Transparency Project (TTP) (2020) also observed that these groups have been encouraged by Trump's tweets about "liberating" states. Despite its resurgence under Trump, the problem of far-right extremism in the US is not new, and its history dates back to the rise of the Ku Klux Klan (KKK) after the Civil War.

In the wake of the 2020 presidential election, the US experienced the greatest risk of serious civil unrest and violent revolt since 1860, when 11 states refused to accept Abraham Lincoln's election as president and eventually seceded from the Union. American citizens have already been armed to the teeth, with record firearms sales during the coronavirus pandemic, especially among first-time gun buyers (Brigety II, 2020). Thousands of these gun owners showed up during the insurrection at the US Capitol on January 6 , 2021, that resulted in five deaths. The crowd falsely claimed the incumbent Trump had won the election and that then President-elect Joe Biden "stole" it through widespread voter fraud. Right-wing protests were also slated to occur at state capitols the weekend of January 17, and the "Boogaloo Boys" (a.k.a. Boogaloo Bois) were among those either planning the protests or planning to attend (SPLC, 2021).

The Boogaloo Boys were also among the most visible participants at state capitol protests after January 6 , and specifically in Richmond, Virginia, on January 18. As a pro-Second Amendment movement, the Boogaloo Boys are easily recognizable because of their Hawaiian-themed Aloha shirts and masks along with their semiautomatic weapons. The shirts are a reference to "big luau," which is an adaptation of the word "boogaloo" (SPLC, 2021). Aloha philosophy is associated with the Native Hawaiian spirit of love, compassion, and mercy - ironic, considering the shirts being worn by Boogalooers at violent demonstrations (Jones, 2021) intended to trigger a civil war to overthrow what they regard as a corrupt establishment (Hinton, 2021).

Despite the occasional adoption by luxury designers, the Aloha shirt is more commonly associated with midlife crises. An article in The New York Times once described the Hawaiian shirt as a "signifier of the style-challenged tourist" (Tudela, 2016). In his book "The Aloha Shirt: Spirit of the Islands," Dale Hope wrote about its "humorous, garish or tacky" associations. 
However, Scot Nakagawa, a senior fellow at ChangeLab, explained that lurid style is a long-held tradition of insurgent white nationalism. The KKK also made use of costumes and mythic rituals as they practiced extreme violence against African-Americans. More modern examples of clothing used by extremist subcultures include the Ben Sherman or Fred Perry shirts, Doc Marten boots, and suspenders worn by neo-Fascist groups from the punk era into 1990s Britain. In addition to identifying members of the groups, wearing these items served as a recruiting tool. Doing so may be an attempt to bait the less informed into assuming the group means no real harm - that they are, really, a goofy bunch of boys despite their military-grade weaponry (Pemberton, 2020).

Having the basic characteristics of anti-establishment far-right populists and seeing the outbreak of violence as something like a party (Giglio, 2020), the Boogaloo Boys use Hawaiian shirts to hide their intentions (Delgado, 2020). The result of an analysis of over 100 million social media comments has confirmed how the "boogaloo meme," "a joke for some, acts as a violent meme that circulates instructions for a violent, viral insurgency for others." According to the researchers, it is like turning off the transponders on 9/11 to enable the extremists to hide in plain sight, disappearing into the clutter of innocent messages (Goldenberg \& Finkelstein, 2020).

This interpretation is shared by Patrick Blanchfield of the Brooklyn Institute. He, and other experts on white nationalist extremism in the US, have stressed that such in-jokes are a longstanding practice of extremist movements born out of online message boards like 4chan and Reddit and, in the case of the Boogaloo Bois, Facebook. Joshua Citarella, a researcher of extremist behaviours on the internet, says this kind of Boogaloo imagery appeared to be "100 percent" co-opted by, among Gen Z, white nationalist groups who wanted not just a confrontation with the establishment, but also a full-fledged race war (Beckett, 2020). However, while a number of empty symbols have been appropriated by groups defined by white nationalist and anti-government ideologies - including Pepe the Frog, the "OK" hand sign, and a purple pigeon emoji - the Aloha shirt represents the first-time extremists have laid claim to a piece of clothing with largely benign associations (Pemberton, 2020).

\section{1}

The term "boogaloo" once represented a fusion of people and cultures, but now refers to an uprising against the establishment, overthrowing democracy, civil war - and even in some quarters, a race war. Boogaloo is no longer about music, but about menace - a word coined by black and brown people now used by some who envision a country without them. 


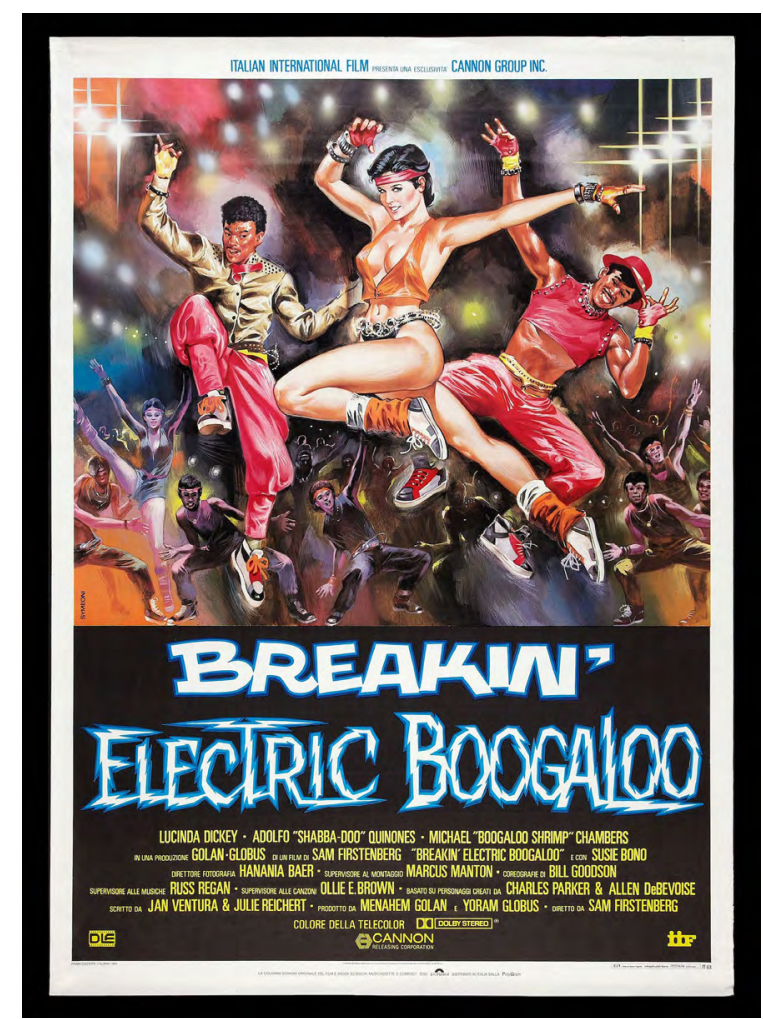

The far-right extremists began referring to an impending civil war using the word "boogaloo," a joking reference to "Breakin' 2: Electric Boogaloo," a 1984 sequel movie.

\section{No Longer About Music And Dance, But About Menace}

The story of the term "boogaloo" is also interesting. The movement was first noticed by extremism researchers in 2019, when fringe groups ranging from gun rights and militia movements to white supremacists began referring to an impending civil war using the word "boogaloo," a joking (Patches, 2014) reference to "Breakin' 2: Electric Boogaloo," a 1984 sequel movie (Zadrozny, 2020; SPLC, 2021) about breakdancing teens battling to save their local community centre from corrupt politicians and corporate development. Sam Firstenberg, the Israel-born movie director of the cult classic explained that the "Electric Boogaloo" began as a meme on the internet. "In the last 10 years or so, it became equal with the word 'sequel," Firstenberg said, in conjunction with the second civil war the Boogaloo movement aspires to create. "Civil War 2: Electric Boogaloo" began popping up on message boards (Abramovitch, 2020).

According to Allam (2020), the movie, which received poorly by critics, became a cult classic. The title has evolved into a meme in a sarcastic way to describe any unwanted sequel. In 1965, the word "boogaloo" emerged as a mash-up of black and Latin American influences. Some 50 years later, the word is still part of American pop culture, but now with a very different meaning. The word once represented a fusion of people and cultures, but now refers to an uprising against the establishment, overthrowing democracy, civil war - and even in some quarters, a race war. Boogaloo is no longer about music, but about menace - a word coined by black and brown people now used by some who envision a country without them (Allam, 2020).

The Boogaloo Boys also use other similar-sounding derivations of the word, including "boog," "boojahideen," "big igloo," "blue igloo," and "big luau" to avoid crackdowns and automated content flags imposed by social media sites to limit or ban Boogaloo-related content (Timberg et al., 2020). Intensified efforts by social media companies to restrict Boogaloo content have caused adherents to use terms even further detached from the original word such as "spicy fiesta" to refer to the movement (Barton, 2020). The Boogaloo movement has created logos and other imagery incorporating igloo snow huts and Hawaiian prints based on these derivations (Charter, 2020; Woodward, 2020). The Boogaloo Boys sometimes carry black-and-white versions of the American flag, with a middle stripe replaced with a stripe of red tropical print and the stars replaced with an igloo. The stripes sometimes list the names of people killed by the police, including Eric Garner, Vicki Weaver, Robert LaVoy Finicum, Breonna Taylor, and Duncan Lemp (Barton, 2020).

Boogaloo memes and ideas have been circulating since the 2010s; however, in the past couple of years, the movement's adherents have been more visible at rallies and events (SPLC, 2021). The Boogaloo movement exploded into the mainstream after it came to light that Sgt. Steven Car- 


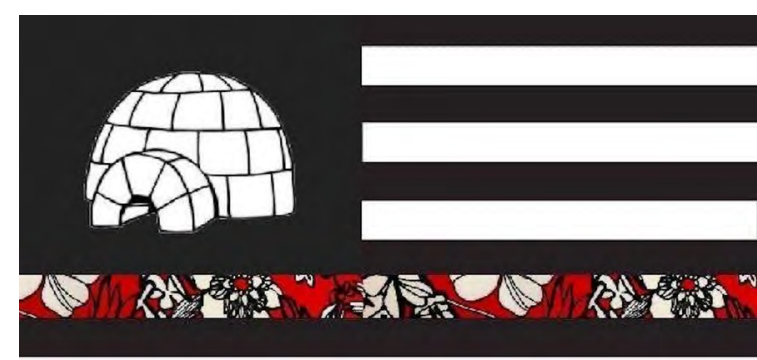

The Boogaloo Boys sometimes carry black-and-white versions of the American flag, with a middle stripe replaced with a stripe of red tropical print and the stars replaced with an igloo.

rillo, who on May 29, 2020 used the cover of the George Floyd protests to gun down one federal officer and injure another in Oakland, California, claims allegiance to the group. Carrillo later scrawled the word "Boog" in his own blood on the hood of a stolen vehicle during a June 6 gun battle with police in Santa Cruz County that also claimed the life of a sheriff's deputy (Abramovitch, 2020).

It is now obvious that the term "boogaloo" has been used to describe an uprising against a supposedly tyrannical or leftwing government, often in response to a perceived threat of widespread gun confiscation. For many, the word "boogaloo" is used jokingly or ironically, but for others, the boogaloo memes are shared alongside violent text and images, seemingly to incite an eventual confrontation. The ambiguity of the term "boogaloo" works to cloak extremist organizing in the open. "Like a virus hiding from the immune system, the use of comical-meme language permits the network to organize violence secretly behind a mirage of inside jokes and plausible deniability," stated a report by the Network Contagion Research Institute (NCRI (Zadrozny, 2020). Goldenberg and Finkelstein (2020) say this ambiguity is a key feature of the problem. Alex Newhouse, digital research lead at Middlebury Institute's Center on Terrorism, Extremism, and Counterterrorism, says "It is very difficult to know if the 'boogaloo boi' you see standing in the middle of the street at a protest is there in solidarity or to incite violence" (Pineda, 2020).

While many still use the boogaloo meme jokingly, an increasing number of people employ the phrase in hopes of inciting the expected apocalyptic confrontation with law enforcement and government officials or to provoke ethnic warfare. Pemberton (2020) noted that it's not uncommon to see heavily armed white men toting military-grade gear on American streets; however, the addition of the Hawaiian shirt is a new twist. The tactics the Boogaloo Boys have used to gain media attention have been honed over the course of decades, by extremist groups from the KKK to the "alt-right": wear distinctive, lurid outfits; give your ideology a weird name; and use bizarre terms that journalists could reveal and decode for their readers. As an example, boogaloo supporters often call themselves the "Boojahideen," a tribute to Afghanistan's Mujahideen, who fought a guerrilla war against the Soviet occupation of their country (Beckett, 2020).

The Boogaloo movement originally grew from the weapons discussion section ("/k/") of the anarchic anonymous message board 4chan where the meme was often accompanied by references to "racewar" and "dotr" ("day of the rope," a neo-Nazi reference to a fantasy involving murdering what the posters view to be "race traitors") (Zadrozny, 2020; ADL, 2019). By 2019, its culture had disseminated across social media into a mix of online groups and chat servers where users shared libertarian political memes. In recent times, this all began to manifest in real life, as users from the groups emerged at protests. The Boogaloo movement - which unites a wide variety of extremist and fringe movements, subcultures, andpeople (ADL, 2020a), some of whom have attempted to associate with Black Lives Matter and others with neo-Nazism (Crawford, 2020) - is the latest example of a mass of memes escaping from 4chan to become a real-life radical movement. As nationwide unrest intensified at the start of the summer of 2020, many Boogaloo adherents interpreted this as a cue to realize their main fantasy: armed revolt against the US government (Beran, 2020).

Part meme, part subculture, the Boogaloo Boys is a mash-up of anti-government apocalyptic screed, Second Amendment 
evangelism, and dark-humoured satire (Weiner, 2020). Relying heavily on humour makes their messaging more accessible and appealing, while also allowing them to underplay the more disturbing content as jest. This use of humour does not diminish the violence associated with Boogalooers' expressed intent. While some Boogalooers try to frame their support for an armed rebellion only as a defensive measure against state-sponsored aggression, others embrace the notion of a full-scale civil war. To this end, members believe that civilians need to be armed with firearms and explosives to maintain the balance of power between the people and the state. As a decentralized movement that organizes largely online but whose presence has increasingly been felt in the real world, the Boogaloo Boys is a group favoured by the militia, gun rights, and anarcho-capitalist movements (ADL, 2020a).

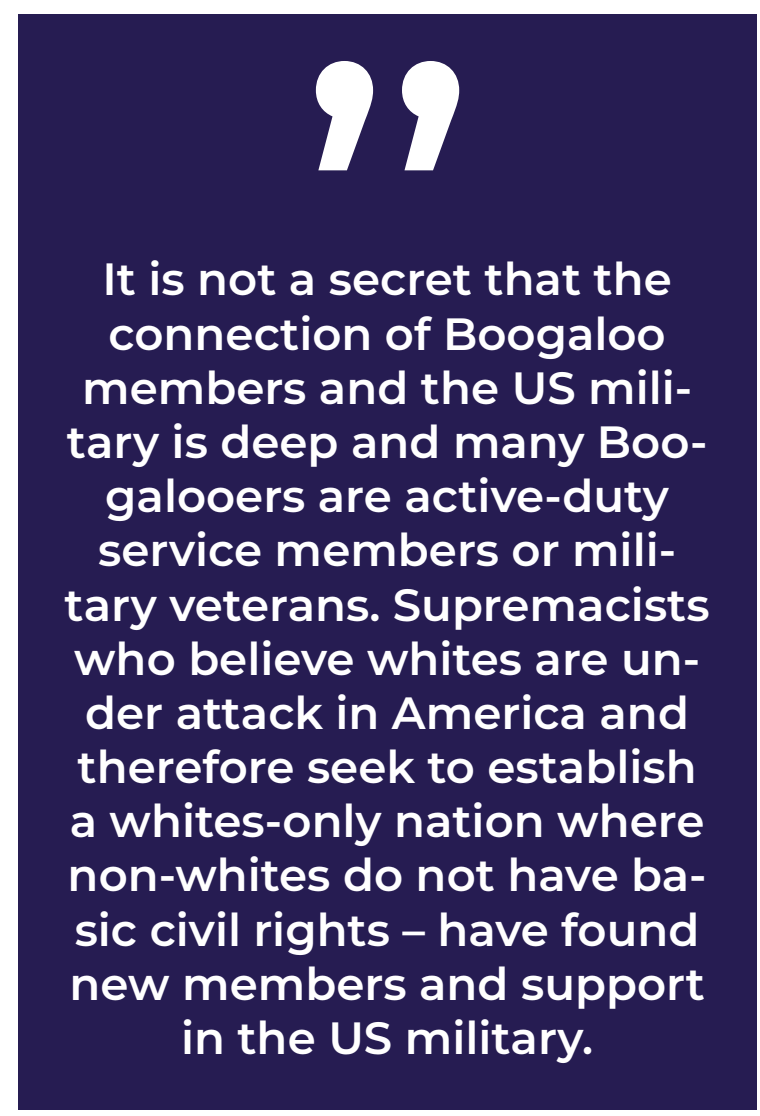




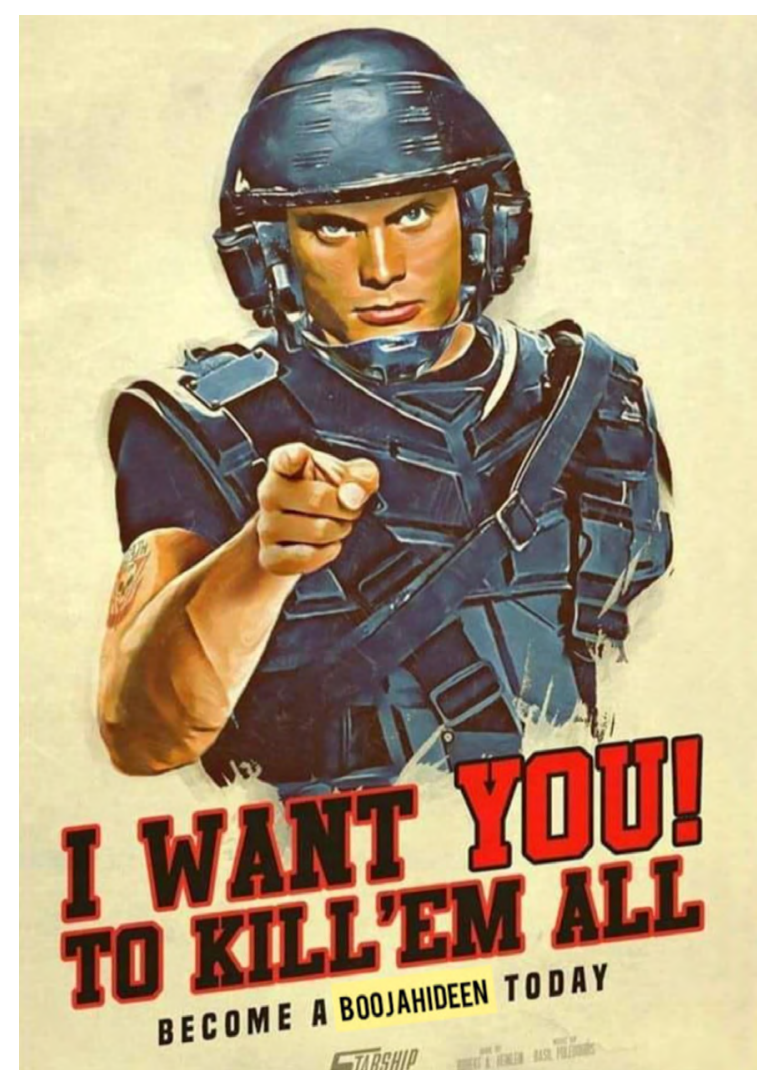

Boogaloo supporters often call themselves the "Boojahideen" as a tribute to Afghanistan's Mujahideen.

\section{Inspired By "The Turner Diaries"}

The unrest related to pandemic restrictions appears to have significantly boosted the profile of the Boogaloo movement. The conspiracy theory that the US government is using the pandemic to restrict American citizens' freedoms has been exacerbated far-right calls for a civil war. Some Boogaloo supporters also believe that the pandemic and subsequent lockdowns have helped raise awareness of their civil war narrative amongst wider populations (Crawford, 2020). Thus, Boogalooers have started articulating how COVID-19 could accelerate and enable the second civil war (ISD, 2020). As hardcore "accelerationists," the Boogaloo Boys promote violence to speed up the collapse of society, and often seek to exploit moments of political or civil unrest, including widespread protests (Owen, 2020).

"Accelerationism" is mainly based on William Luther Pierce's 1978 novel "The Turner Diaries," which is known as "the bible of the racist right" and a novelized blueprint for a white revolution (ADL, 2019) that would instigate a race war and bring about the federal government's collapse (Valasik \& Reid, 2020). The novel depicts the violent overthrow of the government of the US, nuclear conflagration, race war and the ultimate extermination of nonwhites and "undesirable racial elements among the remaining white population" (Sarna, 2021). The widespread and extremely violent conflagration is also often called the "boogaloo" by its adherents (Inglis, 2021). Since publication, "The Turner Diaries" has inspired numerous violent acts, including the April 19, 1995, bombing of the Federal Building in Oklahoma City. Three years later, one of the attackers who murdered a black man in Jasper, Texas on June 7, 1998, also cited "The Turner Diaries" as his inspiration (Berger, 2016).

The novel also features a secret group conspiring to create a "new world order." This idea has taken numerous forms over the decades, from more anti-government beliefs about secret government conspiracies to race-based beliefs suggesting Jewish or minority-based cabals seeking to oppress, control, or replace the white race (Texas Department of Public Safety, 2020). These conspiracy theories are often adopted by groups with a more mainstream aesthetic and less overtly racist aims than their original creators. For instance, the term "white genocide" has given way to "the great replacement" to describe the idea that white people are being systematically replaced by non-whites in Western countries. This makes extreme ideas more palatable for a mainstream audience.

Miller (2020) says the Boogaloo Boys have undergone a similar sanitation process.

On the other hand, according to Goldenberg and Finkelstein (2020), memes such as the boogaloo appear as either cryptic jargon or recreational subcultures to both web users and security experts and, thus, seem an unlikely source for large-scale national security risks. "But it is precisely this unfamiliarity that should signal profound concern: Facing a similarly alien subculture of enthusiasts, national security pundits, the US Military, and intelligence and defence agencies, were entirely caught off guard at the rapid mobilization of ISIS and creation of the caliphate. Foreign 
fighters from all corners of the worldhaving little knowledge of ISIS ideologies, religion, or cause - were quickly recruited from flash to bang through savvy social media outreach," write the authors. They add: "According to our research, boogaloo enthusiasts, who refer to themselves as the 'Boojahideen' may have stolen a page from the ISIS' playbook" (Goldenberg \& Finkelstein, 2020).

Moreover, Brenton Tarrant's "The Great Replacement" manifesto is the latest in a line of theories inspiring acts of domestic terrorism. In fact, prior to Tarrant's manifesto, French author Renaud Camus released his 2012 book "Le Grand Remplacement," arguing that immigrants are replacing European whites (Williams, 2017). These theories share a common theme of blending anti-government sentiments with racial bias to create dystopian images designed to inspire fear and violent acts (Berger, 2016). According to Amy Cooter of Vanderbilt University, some far-right groups have adopted "accelerationism" as "the idea that inducing chaos, provoking law enforcement, and promoting political tension will hasten the collapse of Western government, making room for them to establish a whites-only country" (Valasik \& Reid, 2020). Therefore, the Boogaloo Boys have made police brutality one of their central issues (Owen, 2020).

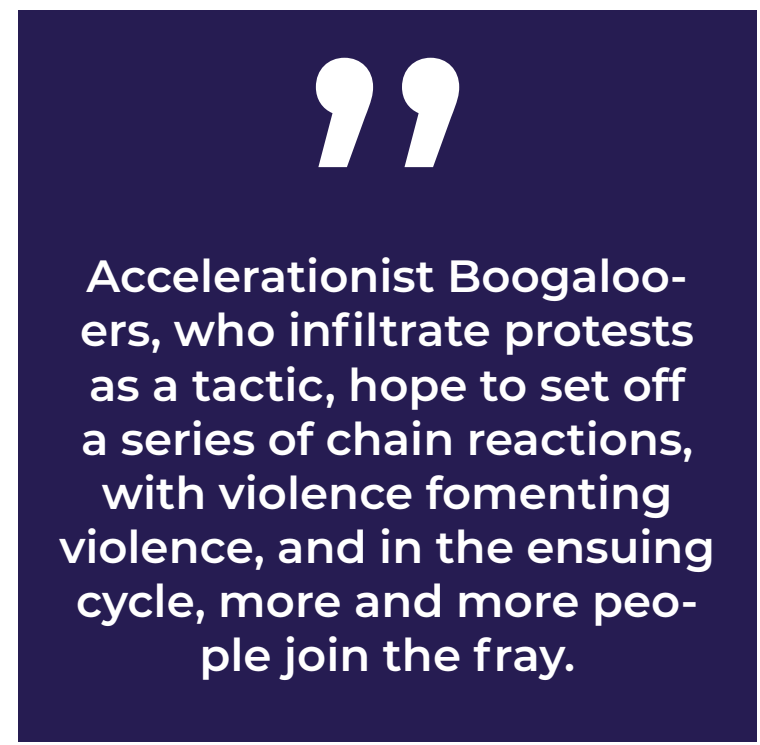




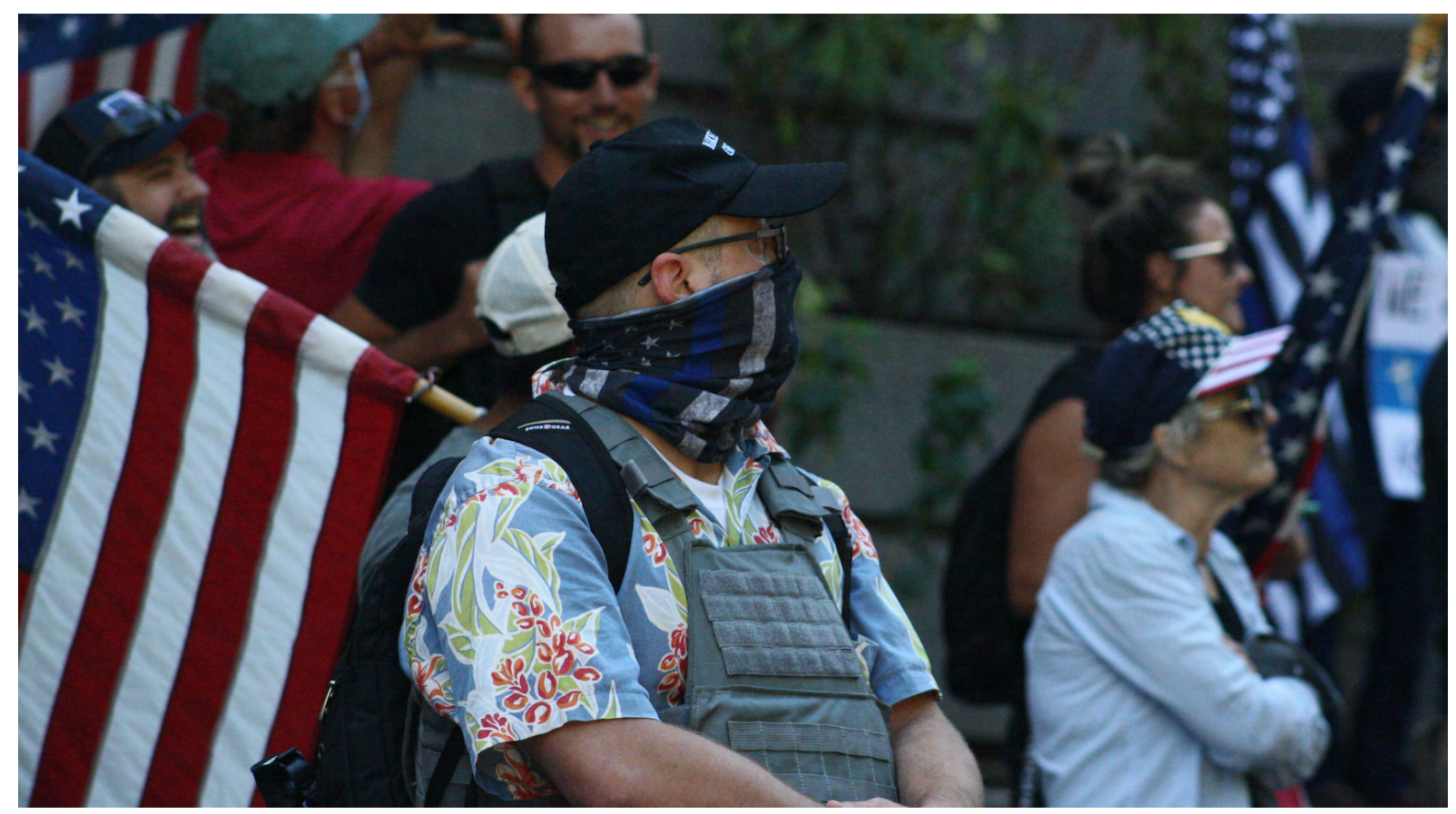

Conservative people from the far right movement, Proud Boys, and Boogaloo Boys join for a "Back the Blue" rally in Portland, Oregon/US on August 22, 2020. Photo: Robert P. Alvarez.

\section{Accelerationist Boo- galooers Infiltrate Protests As A Tactic}

Accelerationist Boogalooers, who infiltrate protests as a tactic (Beeman, 2020), hope to set off a series of chain reactions, with violence fomenting violence, and in the ensuing cycle, more and more people join the fray. When confronted with extremes, so the theory goes, those in the middle will be forced off the fence and go to the side of the white supremacists. If violence can be increased sufficiently, the system will run out of lackeys and collapse, and the race war will commence (Byman, 2020). Accelerationists also take a nod from a Neo-Nazi, James Mason, who came into his ideas as a teenager in the 1960s and published a newsletter, Seige, from 1980 to 1986. Mason believed, "that only the full collapse of American democracy and society will bring conditions sufficient to bring order through Nazism" (Beeman, 2020). For accelerationism to succeed, traditional politics must fail. Dialogue, compromise, and steady progress are its enemies (Byman, 2020).

Despite the Boogaloo Boys creating a considerable sensation in recent times, no one has yet emerged as a "boogaloo" leader or a boogaloo spokesperson, and it's far from clear how many people consider themselves affiliated with "boogaloo" ideology. As of April 2020, more than 100 "boogaloo" groups on Facebook had a total of more than 72,000 members, according to a report released by the Tech Transparency Project (2020). However, some of those users might be double-counted as members of multiple groups (Beckett, 2020). Nevertheless, it is a fact that the "boogaloo" boasts tens of thousands of social media users, exhibits a complex division of labour, evolves well-developed channels to innovate and distribute violent propaganda, deploys a complex communication network on extremist, mainstream, and dark web communities, and articulates a hybrid structure between lone-wolf and cell-like organization (Goldenberg \& Finkelstein, 2020).

On January 20, 2020, thousands descended on Richmond, Virginia, for the Virginia Citizens Defence League's annual Lobby Day. As participants of the rally, the Boogaloo Boys donned Pepe the Frog iconography as well as patches evocative of the American flag emblazoned with an igloo in place of the 50 stars. Some Booga- 
loo members wore a skull balaclava, which is considered the face of 21st-century fascism. A participant boastfully declared on the Facebook page, "Some of the guys we were with aren't exactly out of the military yet, so they had to keep their faces covered" (Goldenberg \& Finkelstein, 2020). It is not a secret that the connection of Boogaloo members and the US military is deep and many Boogalooers are active-duty service members or military veterans (Beran, 2020). White nationalists - people who believe whites are under attack in America and therefore seek to establish a whites-only nation where nonwhites do not have basic civil rights - have found new members and support in the US military (Inglis, 2021).

Military service has, traditionally, been a vehicle for marginalized individuals to make citizenship claims as a result of their military service (Burk, 1995). Yet extremist movements that run counter to integration and inclusion have also been attracted to military service - for a different reason. The links between the US military and white nationalists date back to the 1990s, with many believers seeing military service as an opportunity to hone their fighting skills and recruit others to their movements, particularly after serving (Belew, 2014). However, most Americans don't know much about the level of white nationalism in the military (Spindel et al., 2020), while many do not view it as a serious problem. In particular, self-identified conservatives and those who hold highly favourable views toward the military are less likely to view white nationalism in the military as a serious problem (Ralston et al., 2020).

In 2017 and 2019, two Military Times polls found that about a fifth of respondents reported seeing signs of white nationalism or racist ideology within the armed forces (Shane, 2017, 2019). Nearly 42 percent of non-white troops said they have personally experienced examples of white nationalism in the military, versus about 18 percent of white service members (Shane, 2017). This figure jumped significantly in a 2020 poll, when 36 percent of participants reported seeing evidence of white supremacist and racist ideologies in the military (Shane, 2020). The 2019 survey additionally found that about 35 percent saw the problem of white nationalism as a significant threat to the country (Shane, 2019).

Civilian leaders and the general public have reason to be concerned if the military becomes a fertile recruitment ground for violent and extremist groups (Holthouse, 2006; Levinson, 2019). White nationalists with military service have committed mass acts of deadly violence after leaving the military (Ralston et al., 2020). The issue of extremists in the ranks gained national attention in 2019 after the arrest of Coast Guard Lt. Christopher Hasson, a former active-duty Marine and Army guardsman, who was plotting a mass murder of political and media figures (Shane, 2019).

The problem of white supremacy isn't just limited to the military. "With their enormous power, department-issued weapons and access to sensitive information police departments have also become attractive recruiting grounds for white supremacist groups," says Vida Johnson, a law professor at Georgetown University (Inglis, 2021).

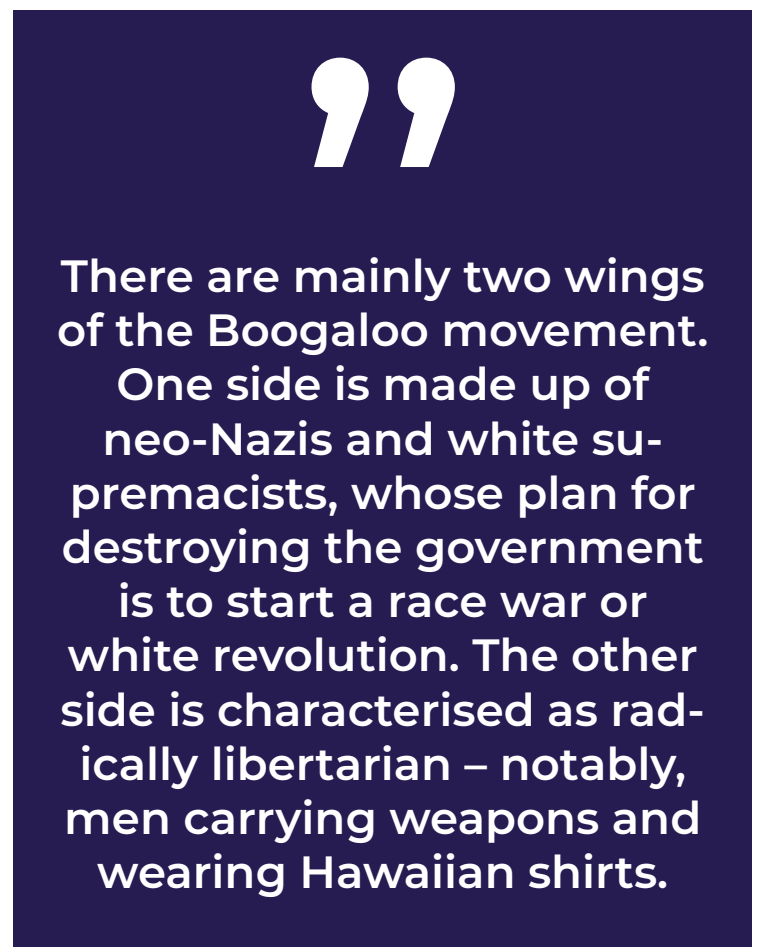


Since 2019, at least 31 people affiliated with the Boogaloo movement have been charged with crimes, including those who killed two security and law enforcement officers in California in May and June 2020 (Beckett, 2020a), a plot to kidnap Michigan Governor Gretchen Whitmer (Brigety II, 2020; Thompson \& Fischer, 2021), incidents related to the George Floyd protests, and the storming of the US Capitol building. All of the Boogaloo Boys arrested were white (Perper \& Sheth, 2020). While the number of active and former military members is believed to be small when compared to the overall size of the movement, extremism researcher Kathleen Belew has stated that their participation "is not a problem we should take lightly" due to the threat that they could "dramatically escalate the impact of fringe activism, pass on explosives expertise, [or share] urban warfare expertise" (Owen, 2020a).

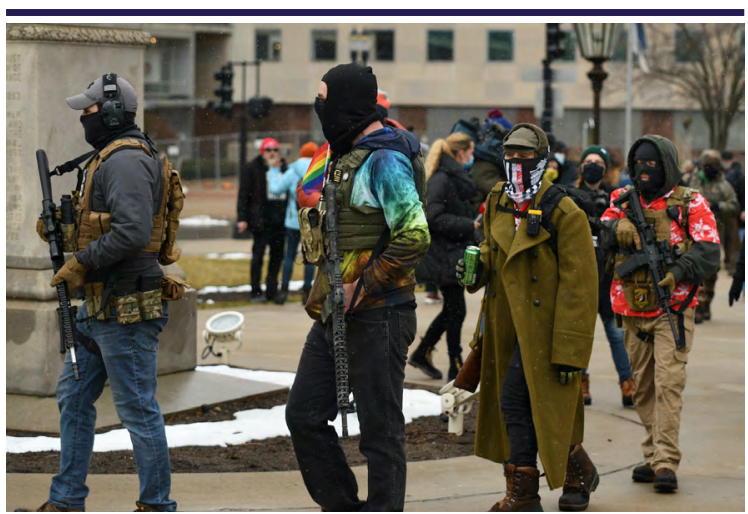

Armed protestors including Boogalooers arrive to support Donald Trumps baseless claims of election fraud in Lansing, Michigan, US on January 17, 2021. Photo: Lester Graham

\section{Some Boogaloo Boys Are Explicit White Nationalists And Neo-Nazis}

The Boogaloo Boys is a loosely affiliated far-right movement that includes a variety of extremist factions and political views. According to Joan Donovan of Harvard's Kennedy School of Business, there are always racialized and eugenic sub-themes in groups like the Boogaloo Boys. "It's about who should live," he said (Beckett, 2020). "You have everyone from neo-Nazis and white nationalists to libertarians," said Cassie Miller, a senior research analyst at the SPLC. What unites them is their interest in having complete access to firearms, the belief that the country is heading towards a civil war (Jones, 2021), and that mass civil conflict of this kind is the only way for the country to correct its path.

These anti-government beliefs have found support beyond the movement's racist roots, making it adaptable and easily spread (SPLC, 2021). Boogaloo Boys urge people to rise up against the government, which they see as tyrannical and essentially irredeemable (Jones, 2021). TTP's analysis also found that some members' profiles include white supremacist content, including images of Adolf Hitler, despite other group members rejecting white supremacist ideology (Mathias, 2020). J. J. MacNab of George Washington University believes participants were radicalized elsewhere prior to donning a Hawaiian shirt. She claims the Boogaloo movement "isn't really a movement. It's a dress code, it's a way of talking, it's jargon" (MacNab, 2020).

The Boogaloo culture operates as a diffuse movement rather than a traditional group organizational structure, with a single leader presiding (SPLC, 2021). According to Alex Newhouse of Middlebury Institute's Center on Terrorism, Extremism, and Counterterrorism, there are mainly two wings of the Boogaloo movement. One side is made up of neo-Nazis and white supremacists, whose plan for destroying the government is to start a race war or white revolution. The other side is characterized as radically libertarian - notably, men carrying weapons and wearing Hawaiian shirts (Pineda, 2020; Beran, 2020). While the white supremacist side veers into overt racism and makes no secret their desire for violence (Owen, 2020) the libertarian side takes offense at the "white supremacist" label (Pineda, 2020). Pineda argues that the group's original members had ties to neo-Nazis and white supremacists, while many newer members are libertarian.

There's no question that some Booga- 
loo Boys are explicit white nationalists and neo-Nazis who use the term "boogaloo" as a synonym for the coming race war. But there's real disagreement, even among experts, about whether the Boogaloo movement as a whole should be described as "white supremacist." Some members of the Boogaloo Boys even denouncewhite supremacists, saying they want to stand in solidarity with Black Lives Matter while other members make racist and anti-Semitic comments and mocked moderators for trying to be politically correct. However, numerous experts say that lip service from some Boogaloo supporters about wanting to be a multi-racial movement should not be taken seriously(Beckett, 2020a; SPLC, 2021).

At the protests after George Floyd's death, Boogaloo Boys were a conspicuous presence. Despite the members being overwhelmingly white, the movement has often presented itself as a race-blind. The Boogaloo meme itself emerged concurrently in white power online spaces in the early 2010 s, today the term is regularly deployed by white nationalists and neo-Nazis who want to see society descend into chaos so that they can build a new fascist state (Miller, 2020). It is true that Boogaloo Boys participated in the rallies, and a few even supposedly sported Black Lives Matter (BLM) patches and rainbow flag patches, in alleged support of the BLM movement and LGBTQ rights. However, it's unclear how much of this support is genuine, and how much is simple political opportunism as the movement attempts to muddy ideological boundaries in order to triage their image and draw in more adherents (SPLC, 2021)

Despite this ideological messiness, it is telling that most of the movement's "martyrs" are white men and women killed at the hands of law enforcement. It was also a white man, Duncan Lemp, who first galvanized the movement - not the deaths of the thousands of Black people killed by police (SPLC, 2021). It is only white men who the Boogaloo Boys view as deserving of liberty and autonomy; their deaths at the hands of the state are evidence of tyranny and injustice, while the deaths of black people largely are not. Viewed from this perspective, the Boogaloo Bois' effort to join the BLM protests reads as nothing more than political opportunism (Miller, 2020). The only place Boogaloo and BLM activists seem to overlap is in their anger toward law enforcement, but the source of their grievances, proposed remedies, and visions for the future are completely distinct (SPLC, 2021). One way to capture the complex dynamics of "Boogaloo" ideology is to label it as a broad anti-government movement that is full of white power activists, believes Belew. Like the militia movement of the 1990s, not everyone who participates in "Boogaloo" events or groups is necessarily a white power activist, she added. (Beckett, 2020a).

As part of a larger anti-establishment extremist movement in the US, the Boogaloo Boys includes militia and "patriot" organizations such as the Oathkeepers and the Three Percenters, whose adherents have been implicated in bombings, murders and armed standoffs with federal law enforcement. Moreover, similar to other right-leaning extremist movements, the members of the movement are the product of an unhappy generation of young white men (SPLC, 2021)who compare their lot in life with that of men in previous decades and see their prospects diminishing. And with a mix of ignorance and simplicity, they view their discontent through the most distorted lens imaginable: internet memes (Beran, 2020). Therefore, like other most visible rightwing populist (RWP) social movements, the Boogaloo movement also prioritizes appealing to young male supporters (DeCook, 2018). Such appeals resonate with nationalist ideologies that emphasize traditional patriarchal gender relations and hostility to feminism and stand in opposition to the liberal, pluralist values purportedly advanced by "the elite" (Bornschier and Kriesi, 2012).

\section{Working-class And Low-income Groups Form The Core}

On the other hand, class remains one of the most striking indicators of support. Working-class and low-income groups have formed the core of the Boogaloo 
movement (Bornschier and Kriesi, 2012). However, according to Beran (2020),Boogaloo Boys certainly do not face the economic disadvantages of the most marginalized groups in the US, but like the alt-right, they are unhappy enough to form their own radical identity politics of collective grievances. Lower educational achievement is also associated with an affinity for the movement (Gidron and Hall, 2017). Indeed, Boogalooers often use anti-intellectualism as a tool, clumping elites and the educated together and encouraging a rejection of the "experts" (Merkley, 2020). What these men share is years of marginalization and a hatred of the present state of society (Beran, 2020).

It is not so abnormal for Boogaloo Boys to see the current federal government as illegitimate, while remaining deeply "patriotic." They revere the Constitution and see themselves as the true descendants of America's founding fathers. In their view, current US lawmakers are the equivalent of occupying British forces during the Revolutionary War. Among the "boogaloo" merchandise for sale online are images of George Washington armed with a modern, AR-15-style rifle (Beckett, 2020a). The Boogaloo Boys are entirely opposed to firearm regulations (SPLC, 2021).

"It's ANTIFA and the Radical Left," Trump tweeted on May 30, 2020. "Don't lay the blame on others!" During Trump's administration, the Department of Homeland Security claimed the Boogaloo movement was not right wing - a claim disputed by experts. Trump's unwillingness to name and shame far-right groups publicly is not harmless (Bertnard, 2020).While some anarchists have embraced "Boogaloo" rhetoric, these are primarily "right-wing anarchists," who believe in "unfettered capitalism" - not left-wing anarchists, says Mark Pitcavage of the ADL (Beckett, 2020a). Newhouse also says the Boogaloo movement is a far-right movement. The Guardian has reported that experts on extremism concur that the Boogaloo movement is right wing. Daryl Johnson, a former DHS analyst, believed the DHS' claim that the Boogaloo movement is not right wing, was "playing politics" (Beckett, 2020).

A clear sign that the Boogaloo Boys are right wing is their decision to show up with guns to guard private businesses, first during demonstrations against public health shutdown restrictions, and later during the protests over Floyd's killing. Showing up with guns to protect big corporations from property damage is not something that most left-wing protesters would do (Beckett, 2020a). Thus, the claim that the Boogaloo Boys is not a right-wing movement does not reflect reality.

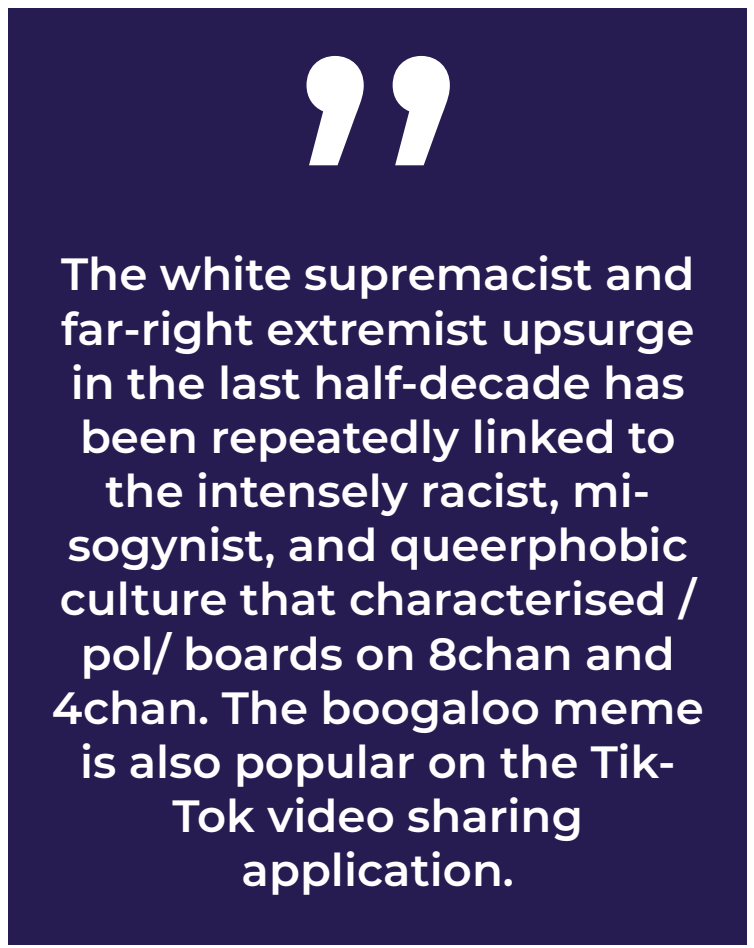



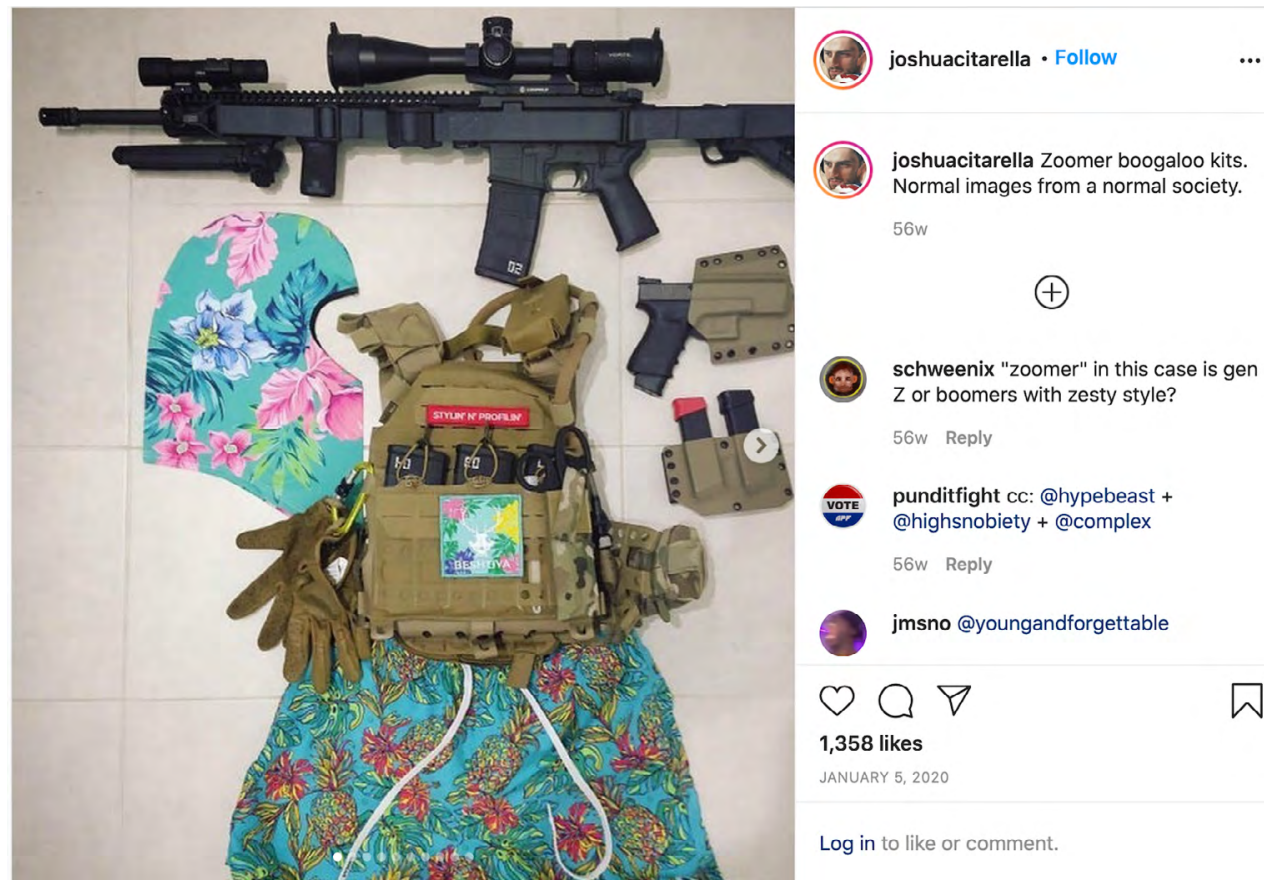

\section{Social Media (Face- book): Boogalooers' Fertile Habitat}

The Boogaloo Boys, which stemmed from memes in social media pro-gun groups, have organized through Facebook, Reddit, and YouTube (Pineda, 2020). However, the true birthplace of the movement is 4chan's / $/$ / section (Evans \& Wilson, 2020), which is ostensibly devoted to the ownership and purchase of weapons, from knives to fighter jets. Half-serious posts about how certain weapons might be employed in "the boogaloo" evolved over time. Like many memes on 4chan, each new version was more cryptic than the last, a means to express insider knowledge and in-group status (Beran, 2020).

One example of this is how "Boogaloo," itself a euphemism, has been further disguised with the use of soundalike terms like "big luau" and "big igloo." The term "icehouse" is yet another synonym for the term, descended from the "Big Igloo" variation (Evans \& Wilson, 2020). Even the co-option of Hawaiian imagery and igloos is inherently cynical and meaningless. There is no connection to the group's ideology outside of the linguistic resemblance of the word "boogaloo" to "igloo" or "Iuau." But this co-option fits the ethos of online spaces perfectly, with a niche group celebrating its anti-government views by draping them in colourful jokes and nonsense that can be endlessly remixed and reinterpreted (Beran, 2020).

The white supremacist and far-right extremist upsurge in the last half-decade has been repeatedly linked to the intensely racist, misogynist, and queerphobic culture that characterised /pol/ boards on 8chan and 4chan. The boogaloo meme is also popular on the TikTok video sharing application, where the \#Boogaloo hashtag had over two million views as of June 2020 (Owen, 2020b).

Some of the most active Boogaloo communities were on Discord, a chat program popular among online gamers (Bertnard, 2020). However, following media coverage - which included screenshots of a Discord server where members of the military were sharing their expertise - Discord shut down the server and deleted the accounts of its members. The community created and migrated to a subreddit after their removal from Discord, but Reddit banned the subreddit shortly afterward (Rodriguez, 2020). The website Tree of Liberty, which described itself as the "press platform" for the Boogaloo movement, was also taken offline by its cloud hosting provider on January 12, 2021 (Mac 
\& Haskins, 2020). A Twitter spokesperson said that Twitter views Boogaloo content as free expression and does not ban accounts solely for their use of the term, but that they had banned numerous accounts that used the term for violating other policies.
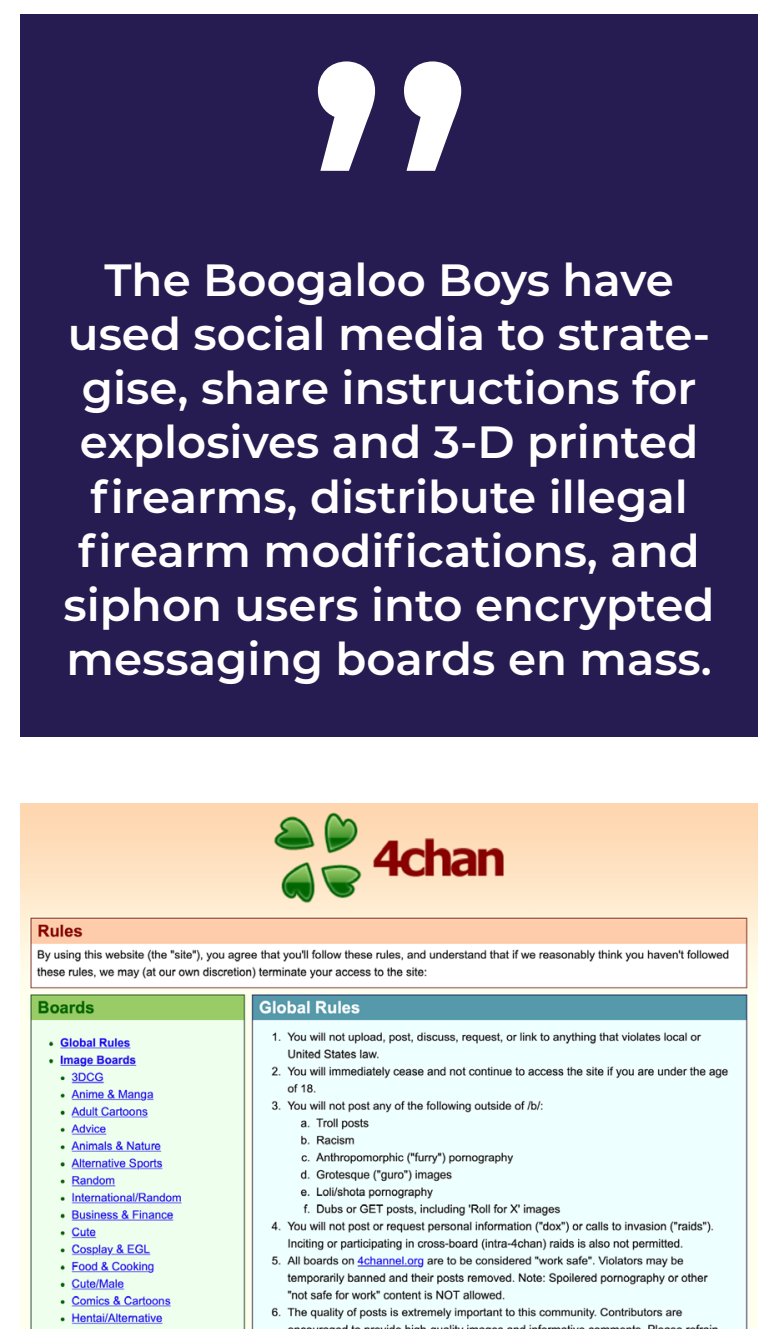

The Boogaloo movement originally grew from the weapons discussion section ("/k/") of the anarchic anonymous message board 4chan.

\section{4chan Birthed Boo- galooers, Facebook Helped To Grow}

Though 4chan birthed the Boogaloo Boys, above all, it is Facebook that has helped the group grow (Evans \& Wilson, 2020). Researchers have repeatedly drawn attention to Facebook's role in radicalizing extremist actors, and the consequences of allowing extremists to organize freely on the platform, to little practical avail. Research by the TTP showed that there were at least 125 Facebook groups devoted to the Boogaloo movement on April 22, 2020. The real number has since increased significantly, although determining an exact number is all but impossible due to the rapid evolution of the subculture (Evans \& Wilson, 2020). Online extremists have used Facebook to plan and organize for a militant uprising in the US as they cast coronavirus lockdowns as a sign of rising government suppression (Pineda, 2020). NCRI researchers, who analysed more than 100 million social media posts and comments, found that through the use of memes extremists have pushed anti-government and anti-law enforcement messages across social media platforms. They have also organized online communities with tens of thousands of members, some of whom have assembled at real-world events (Zadrozny, 2020). Facebook management has long understood its role in promoting extremism but have elected not to act for fear of alienating conservative sensibilities, especially in the US (Evans \& Wilson, 2020).

The Boogaloo Boys have used social media to "strategize, share instructions for explosives and 3-D printed firearms, distribute illegal firearm modifications, and siphon users into encrypted messaging boards en mass," according to the NCRI report. The report also notes how the boogaloo concept has been monetized, through merchandise advertised through Facebook and Instagram ads, and marketed to current and former members of the military (Zadrozny, 2020). A range of boogaloo-related phrases emerged as the term became more popular in social media, including: "showing up for the boogaloo," "when the boogaloo hits," "being boogaloo ready" and "bring on the boogaloo." Boogaloo-related hashtags have surfaced, including \#boogaloo2020, \#Biglgloo, \#boojahideen, and \#boogaloobois. The boogaloo meme soon spread from angry gun-rights activists to the militia movement and survivalists. The Telegram channel, "Boogaloo: How to Survive," claims to show "how to survive in a post-society world through understanding the psychology of violence, attaining resources, and organizing to accomplish 
post society tasks" (ADL, 2019).

On public Facebook pages, Boogalooers circulate satirical posts about the overthrow of government, painting the Boogaloo as a viral online phenomenon rather than a real-world threat. But communications of boogaloo supporters in private Facebook groups accessed by TTP tell a different story: extremists exchanging detailed information and tactics on how to organize and execute a revolt against American authorities. This activity is occurring without any apparent intervention by Facebook. TTP found 125 Facebook groups devoted to the "boogaloo." In several private boogaloo Facebook groups, members discussed tactical strategies, combat medicine, and various types of weapons, including how to develop explosives and the merits of using flame throwers (Tech Transparency Project, 2020). One group even shared a document detailing how to disrupt US government supply lines and discussing the possible need to assassinate government officials (Mathias, 2020). Some Boogalooers see the public health lockdowns and other directives by states and cities across the country as a violation of their rights, and they're aiming to harness public frustration at such measures to rally and attract new followers to their cause (Tech Transparency Project, 2020).

A study by the Institute for Strategic Dialogue (ISD) found that "COVID-19 is being used to advance calls for the "boogaloo,"' and that two boogaloo-related Facebook groups have seen large spikes in engagement. One of the groups, Big Igloo Bois, saw an 88 percent jump in interactions in March 2020, according to the study (ISD, 2020). Moreover, Trump's tweets about liberating Virginia, Michigan, and Minnesota appear to have energized some elements of the Boogaloo movement. Among the most popular boogaloo-themed pages on Facebook is Thicc Boog Line, a boogaloo clothing brand that has attracted nearly 30,000 followers since its October 2019 founding (Tech Transparency Project, 2020).

Despite many warnings from reporters and civil society organizations and employing 350 people on staff devoted to stopping people and organizations from using its platform to plot or engage in violence (Mathias, 2020), Facebook failed to remove the violent content proliferating on Boogaloo-related groups for months enough time for the disjointed movement to congeal, organize, and grow its ranks (SPLC, 2021). Eventually, on May 1, 2020, Facebook and Instagram both updated their "violence and incitement" policy to ban the use of the term Boogaloo and related words when they occur alongside images or statements depicting or urging armed violence (Evans \& Wilson, 2020; Pineda, 2020) and designated a network of "Boogaloo" groups as a dangerous organization similar to the ISIS (Beckett, 2020a).

However, at the same time, research suggests that this policy has done virtually nothing to curb either the growth of the Boogaloo movement or reduce the violence of its rhetoric. Facebook remains a hospitable place for would-be insurrectionists, and it buried evidence that its platform facilitates the growth of extremism, due to a fear that combatting this would be seen as anti-conservative bias. But every day, tens of thousands of heavily armed people log on to repeat their hope for an American civil war (Evans \& Wilson, 2020).

According to researchers, the Facebook groups were particularly dangerous, because they were helping to build local connections between nascent domestic extremists. The company removed 220 Facebook accounts, 95 Instagram accounts, 28 pages, and 106 groups as parts of the Boogaloo-affiliated network "after there were already bodies." Some experts said it was too late: the scattered men drawn to the idea of being soldiers in an insurgency against the American government had already connected with each other directly (Beckett, 2021). In the wake of Facebook's targeted takedown, Boogalooers have encouraged each other to avoid using old nicknames originally used to bypass censorship, phrases like "luau," "igloo," or "boog," in favour of new ones, like "fiesta" (ADL, 2020b).

After Facebook started to de-platform Boogaloo adherents on June 30, 2020, amidst a boycott in which companies including Coca-Cola, Starbucks, and Volkswagen announced they would no 
longer advertise on the platform due to "the hate speech and misinformation that persists on Facebook" (Menn, 2020; Collins \& Zadrozny, 2020), many Boogalooers retreated to other social media platforms. However, some took an alternative path: rebranding their movement on Facebook using the names of prominent media companies. As part of this rebranding effort, Boogalooers on Facebook started to share memes and posts referring to the boogaloo as "NBC," "Fox News," and "Vice." Yet no nickname has been adopted as widely as "CNN," which has boogaloo supporters referring to themselves as "CNN bois" and using \#CNN to refer to the Boogaloo itself (ADL, 202Ob).

Boogalooers believe that emmeshing their cause with a popular brand will make it more difficult for Facebook to remove their content. While Facebook has already removed several of these pages, this latest episode illustrates how quickly the Boogaloo movement is able to adapt and demonstrates the need for continued monitoring to stem the spread of its violent message. Apparently, Boogalooers are better positioned than more formalized groups to adapt to new conditions, because the movement is focused on a concept, not a centralized organization. The name of the group is secondary (ADL, 2020b). 


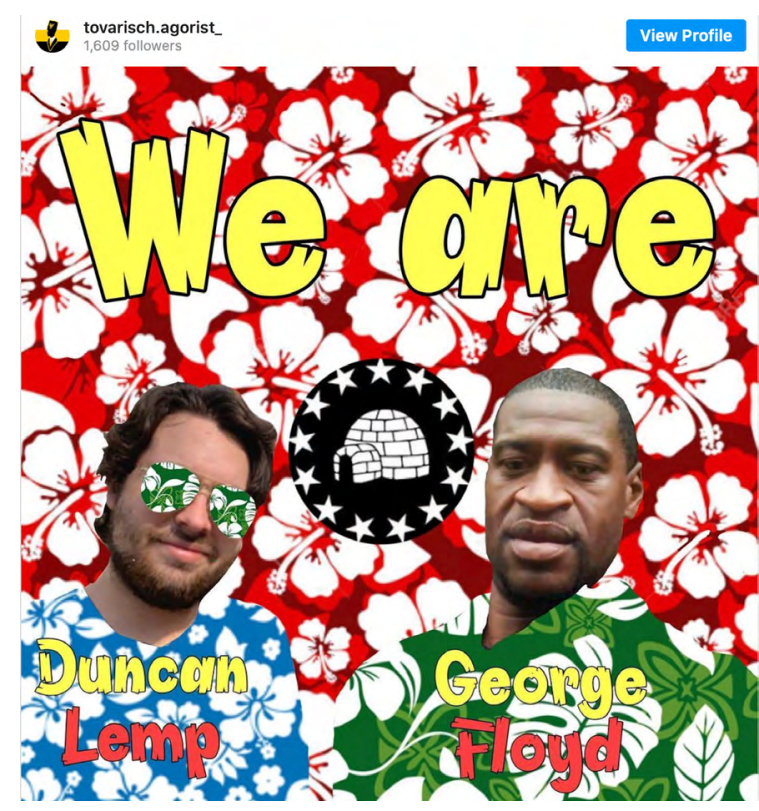

Right-wing activist Duncan Lemp's death helped solidify the nascent Boogaloo movement into a defined online subculture and galvanized their anti-police stance.

\section{Violence: Boogalooers} Target Police As Most Accessible Symbol of Government

As Mudde (2021) notes, far-right extremism has generally been ignored in the US despite the DHS warning that veterans returning from Iraq and Afghanistan might be particular targets for recruitment by extremist groups (DHS, 2009). The report sparked a conservative backlash, which accused the Obama administration of unfairly targeting conservatives and veterans. The situation has gotten worse since. In their effort to create an all-white country, the far-right extremists, including the Boogaloo Boys, often instigate violent confrontations that target racial and religious minorities (Spindel et al., 2020). Especially since 2018, far-right extremists have conducted more lethal attacks than any other domestic extremist movement (DHS, 2020). A CSIS report stated that the right-wing extremists perpetrated two thirds of the attacks and plots in the US in 2019 and over 90 percent between January 1 and May 8, 2020 (Bertnard, 2020; Weiner, 2020).
As was expected, the military and police departments have been infiltrated and compromised by far-right sympathizers. Nearly one in five defendants in Capitol storming cases have served in the military (Mudde, 2021). In parallel, Boogalooers also generate and share memes glorifying the Wehrmacht, the unified armed forces of Nazi Germany, and jittery graphics that borrow from the aesthetics of Atomwaffen and other overtly white supremacist accelerationist groups (Green, 2020). The war in Ukraine has attracted hundreds of foreign fighters with ties to the far-right who use the battlefield as a networking space. That includes dozens of Americans, some of whom have come home with new contacts and fighting experience. Outside Ukraine, white supremacist training camps exist in Poland, Bulgaria, and even the UK, and many white supremacist organizations operate transnationally (Weiner, 2020).

Boogalooers consider the police, which is the most accessible symbol of the government at public gatherings (Jones, 2021), an arm of the state that is enforcing "tyrannical" laws and directives. They foment this anti-law enforcement sentiment with references to past violent incidents as evidence of the government's willingness to kill people who oppose its laws (ADL, 2020a). They refer to police as "soup bois" because federal agencies sometimes are referred to as "alphabet soup" due to their varied acronyms (Dazio, 2020). Boogaloo Facebook groups regularly featured jokes about men filling their lawn sprinklers with gasoline to light the police on fire (Beckett, 2021). One meme, posted in April 2020, showed a person in a helicopter shooting down at feral pigs on the ground with the caption "pig hunting: now." The next image, captioned "pig hunting: boogaloo," showed the same person shooting at cops (Miller, 2020). "If you look at their online spaces, their rhetoric is extremely violent," SPLC's Miller said. "A lot of it is kind of under this veneer of irony and humour, but there's something very real to all of it," (Jones, 2021).

Boogalooers have used the Files function in Facebook groups to upload dozens of planning documents, including military manuals, CIA handbooks, and instructions on how to reuse N95 facemasks, among 
other material. The most concerning document is one entitled Yeetalonians, a reference to the Boogaloo. At over 133 pages, the document provides an in-depth look at preparing for the Boogaloo and offers advice on what weapons should be used, what propaganda to distribute, and how to psychologically win over civilians to the cause. The document mentions "target selection," noting that assassinations of figureheads are "overrated" but "some people have to go." It discusses how to disrupt US government supply lines, noting that "national guard depots, police stations and factories that produce munitions are all very solid targets," (Tech Transparency Project, 2020). According to the TTP report, the group engages in national-level coordination, as state and local chapters are where users share tactical information and survival tips, ranging from topographic map access to instructions for evading authorities (Mathias, 2020).

An assessment dated June 15, 2020, predicted that "violent adherents of the boogaloo ideology likely reside in the National Capital Region, and others may be willing to travel far distances to incite civil unrest or conduct violence encouraged in online forums associated with the movement." It also noted that "while it identifies Washington D.C. as an attractive target, the Boogaloo ideology is not restricted to a specific region and those who wish to cause division are routinely using peaceful protests as means of cover" (Bertnard, 2020).

Right-wing activist Duncan Lemp's death helped solidify the nascent Boogaloo movement into a defined online subculture and galvanized their anti-police stance (SPLC, 2021). Police carrying out a search warrant shot and killed the 21-year-old Lemp during a SWAT raid in March 2020. Lemp's family said he was killed while he was asleep in his bedroom. Groups honouring Lemp popped up in far-right internet spaces (Miller, 2020). In March 2020, a Missouri man (Timothy Wilson, 36) with ties to neo-Nazis was shot and killed when FBI agents tried to arrest him. Wilson told an undercover FBI agent that his goal was "to kick-start a revolution" and referred to his plans as "operation boogaloo" (Pineda, 2020). In May 2020, three Boogaloo members were arrested on terrorism-related charges in what federal prosecutors say was a conspiracy to spark violence during protests in Las Vegas over reopening businesses and Floyd's death. Authorities allege the three white men filled gas cans and made Molotov cocktails in glass bottles and were headed to a BLM protest (Komenda, 2020).

During the riots in May 2020, after Floyd's death, FBI agents got a tip that two members of the Boogaloo Boys had armed themselves. The suspects were talking about killing police officers and attacking a National Guard armoury to steal heavy weapons. The FBI deployed an undercover informant who posed as a member of Hamas and offered to help the suspects obtain explosives and training. After the suspects started talking about a plot to attack a courthouse, agents arrested them (Rotella, 2021). These cases show that, among others, violent instigators affiliated with the Boogaloo movement have hijacked peaceful protests and demonstrations across the country, (Pineda, 2020) for their own purposes (Valasik \& Reid, 2020).

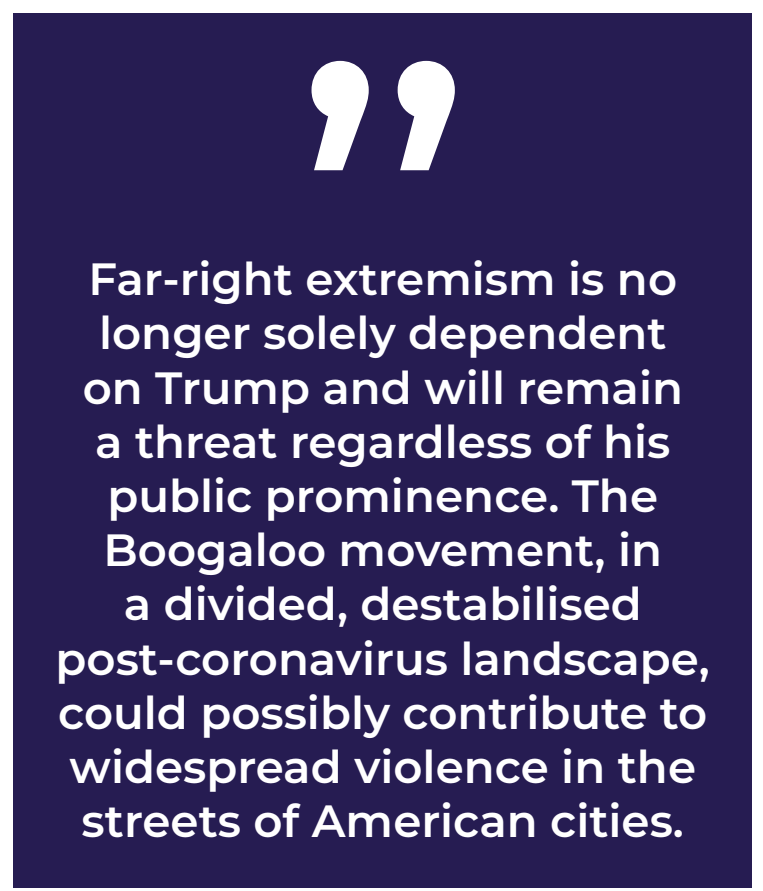




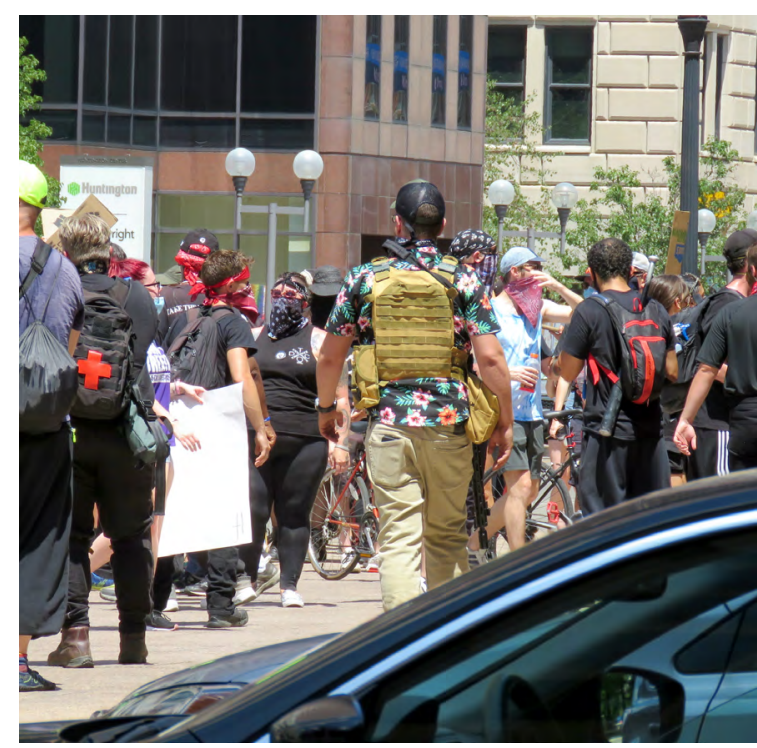

Anti-Mask Rally at the Ohio Statehouse - Boogaloo Boy infiltrates the counter-protest in Columbus, Ohio/ US on July 18. 2020. Photo: Dan Fleckner.

\section{CONCLUSION}

The Boogaloo movement is part of a broader rise in far-right extremism in the US, as was predicted in the early years of the Obama presidency. US law enforcement agencies and the military have faced criticism for doing too little to monitor and prevent the radicalization of American citizens by violent white supremacists and other domestic right-wing extremists (Beckett, 2021) such as the Boogaloo Boys (or Bois).

The pandemic has also been a fertile ground for far-right messaging, opening new platforms to radical activists and extremist movements. Violent extremists across the ideological spectrum have exploited the pandemic to take advantage of people who are at their most vulnerable, desperate, and availablerelegated to their homes with little to distract them aside from surfing the Web. The dearth of large public gatherings and crowds moved the terrorism battlefield inside and on- line. But with an anti-government message designed for online virality, twenty-first-century extremists and accelerationists were especially well positioned to profit from this shift (Weiner, 2020).

As Crawford (2020) underlined, while it is impossible to predict the long-term effects of this trend, it is possible to sell some elements of far-right ideology, like the Boogaloo, to more mainstream audiences. Shifting those people away from these ideas may be as difficult as tackling the virus itself (Crawford, 2020). And the evidence so far suggests that the movement has succeeded in spreading its message a message that can, as the recent arrests of Boogaloo movement adherents show, all too easily turn into real life threats (Weiner, 2020). While adapting themselves to the times, as Hinton (2021) noted, farright extremism is no longer solely dependent on Trump and will remain a threat regardless of his public prominence. The Boogaloo movement, in a divided, destabilized post-coronavirus landscape, could possibly contribute to widespread violence in the streets of American cities. 


\section{REFERENCES}

- (2009). Rightwing Extremism: Current Economic and Political Climate Fueling Resurgence in Radicalization and Recruitment. US Department of Homeland Security (DHS). April 7, 2009. https://fas.org/irp/eprint/rightwing.pdf (accessed on January 30, 2021).

- (2019). "The Boogaloo: Extremists' New Slang Term for A Coming Civil War." ADL. November 26, 2019. https://www.adl.org/blog/the-boogaloo-extremists-new-slang-term-for-acoming-civil-war (accessed on January 29, 2021).

- (2020). "Extremists Are Using Facebook to Organize for Civil War Amid Coronavirus." Tech Transparency Project. April 22, 2020. https://www.techtransparencyproject.org/articles/extremists-are-using-facebook-to-organize-for-civil-war-amid-coronavirus (accessed on January 29, 2021).

- (2020). Far-Right Mobilization - Covid-19 Disinformation Briefing No.2. Institute for Strategic Dialogue (ISD). April9, 2020. https://www.isdglobal.org/wp-content/uploads/2020/04/ Covid-19-Briefing-PDF.pdf (accessed on January 30, 2021).

- (2020a). "Boogaloo Supporters Animated By Lockdown Protests, Recent Incidents." ADL. May 22, 2020. https://www.adl.org/blog/boogaloo-supporters-animated-by-lockdown-protests-recent-incidents (accessed on January 29, 2021).

- (2020b). "Boogaloo, Rebranded." ADL. July 13, 2020. https://www.adl.org/blog/boogaloo-rebranded (accessed on January 29, 2021).

- (2020). Far-Right Mobilization - Covid-19 Disinformation Briefing No.2. Institute for Strategic Dialogue (ISD). April9, 2020. https://www.isdglobal.org/wp-content/uploads/2020/04/ Covid-19-Briefing-PDF.pdf (accessed on January 30, 2021).

- (2020). Texas Domestic Terrorism Threat Assessment. Texas Department of Public Safety. January 2020. https://www.dps.texas.gov/director_staff/media_and_communications/2020/ txTerrorThreatAssessment.pdf (accessed on January 29, 2021).

- (2020). Homeland Threat Assessment. DHS. October 2020. https://www.dhs.gov/sites/default/files/publications/2020_10_06_homeland-threat-assessment.pdf (accessed on February 1, 2021).

- (2020). Threat Awareness Message: Boogaloo Follow-up: Three Members of Boogaloo Movement Arrested by FBI with DoD Connections. MTAC Criminal Threat Division. June 4, 2020. https://www.documentcloud.org/documents/6982452-June-4-NCIS-Threat-Reporton-Boog.html (accessed on February 11, 2021).

- (2020). "Assessing the Threat From Accelerationists and Militia Extremists." (Congressional hearing). Oral testimony by J. J. MacNab. United States House Homeland Security Subcommittee on Intelligence and Counterterrorism. July 16, 2020. https://homeland.house. gov/activities/hearings/assessing-the-threat-from-accelerationists-and-militia-extremists (accessed on February 11, 2021).

- (2021). "Who Are Boogaloos, Who Were Visible at the Capitol and Later Rallies?" SPLC. January 27, 2021. https:/www.splcenter.org/hatewatch/2021/01/27/who-are-boogaloos-whowere-visible-capitol-and-later-rallies (accessed on January 30, 2021).

Abramovitch, Seth. (2020). "'Breakin' 2: Electric Boogaloo' Director on Boogaloo Extremists: "A Surrealistic Situation." Hollywood Reporter. June 17, 2020. https://www.hollywoodreporter.com/news/breakin-2-electric-boogaloo-director-boogaloo-extremists-a-surrealistic-situ- 
ation-1299017 (accessed on February 8, 2021).

Allam, Hannah. (2020). "'Boogaloo' Is The New Far-Right Slang For Civil War." NPR. January 10, 2020. https://www.npr.org/2020/01/10/795366630/boogaloo-is-the-new-far-right-slangfor-civil-war (accessed on January 29, 2021).

Barton, Gina. (2020). "Young white men with long guns at George Floyd protests likely affiliated with far-right group Boogaloo." Milwaukee Journal Sentinel. June 5, 2020. https:/l eu.jsonline.com/story/news/2020/06/04/armed-white-men-milwaukee-protests-could-farright-boogaloo/3147128001/ (accessed on February 10, 2021).

Beckett, Lois. (2020). "How Facebook and the White House let the 'boogaloo' movement grow." The Guardian. July 1,2020. https://www.theguardian.com/world/2020/jul/01/ what-is-boogaloo-movement-rightwing-anti-government (accessed on January 30, 2021).

Beckett, Lois. (2020a). "White supremacists or anti-police libertarians? What we know about the 'boogaloo'." The Guardian. July 8, 2020. https://www.theguardian.com/ world/2020/jul/08/boogaloo-boys-movement-who-are-they-what-do-they-believe (accessed on February 1, 2021).

Beckett, Lois. (2021). "100 days of warning: inside the Boogaloo killings of US security personnel." The Guardian. January 15, 2021. https://www.theguardian.com/world/2021/jan/15/ boogaloo-killing-facebook-dave-patrick-underwood-police (accessed on January 30, 2021).

Beeman, Amy. (2020). "The Boogaloo Movement: 5 Fast Facts You Need to Know." heavy. com. June 4, 2020. https://heavy.com/news/2020/06/the-boogaloo-movement-5-fast-facts/ (accessed on February 1, 2021).

Belew, K. (2019). Bring the war home: The White power movement and paramilitary America. Harvard University Press.

Beran, Dale. (2020). "The Boogaloo Tipping Point." The Atlantic. July 4, 2020. https://www. theatlantic.com/technology/archive/2020/07/american-boogaloo-meme-or-terrorist-movement/613843/ (accessed on January 30, 2021).

Berger, J.M. (2016). The Turner Legacy: The Storied Origins and Enduring Impact of White Nationalism's Deadly Bible. International Centre for Counter-Terrorism. September 16, 2016. https://icct.nl/publication/the-turner-legacy-the-storied-origins-and-enduring-impact-of-white-nationalisms-deadly-bible/ (accessed on February 8, 2021).

Bertnard, Natasha. (2020). "Intel report warns that far-right extremists may target Washington, D.C." Politico. June 19, 2020. https://www.politico.com/amp/news/2020/06/19/intelreport-warns-far-right-extremists-target-washington-dc-329771 (accessed on February 1, 2021).

Byman, Daniel L. (2020). "Riots, white supremacy, and accelerationism.” Brookings.

June 2, 2020. https://www.brookings.edu/blog/order-from-chaos/2020/06/02/riots-white-supremacy-and-accelerationism/ (accessed on February 1, 2021).

Bornschier, S. \& Kriesi, H. (2012). "The Populist Right, the Working Class, and the Changing Face of Class Politics." P. 10-30. In: J. Rydgren, ed., Class Politics and the Radical Right. London: Taylor and Francis Group.

Brigety II, Reuben E. (2020). "If America Were in Africa." Foreign Affairs. October 19, 2020. https://www.foreignaffairs.com/articles/africa/2020-10-19/if-america-were-africa (accessed on January 29, 2021). 
Burk, J. (1995). "Citizenship status and military service: The quest for inclusion by minorities and conscientious objectors." Armed Forces \& Society. 21, 503-529.

Crawford, Blyth. (2020). "Coronavirus and conspiracies: how the far right is exploiting the pandemic." The Conversation.September 15, 2020. https://theconversation.com/coronavirus-and-conspiracies-how-the-far-right-is-exploiting-the-pandemic-145968 (accessed on February 1, 2021).

Charter, David. (2020). "'Boogaloo boys' prepare for next American civil war in Hawaiian shirts." The Times. May 16, 2020. https://www.thetimes.co.uk/article/boogaloo-boys-prepare-for-next-american-civil-war-in-hawaiian-shirts-wsmdmmclm (accessed on February 10, 2021).

Collins, Ben \& Zadrozny, Brandy (2020). "Facebook to remove anti-government 'Boogaloo' groups." NBC News. June 30, 2020. https://www.nbcnews.com/tech/tech-news/facebook-remove-anti-government-boogaloo-groups-n1232579 (accessed on February 11, 2021).

Dazio, Stefanie. (2020). "Air Force sergeant faces murder charges in killings of federal security officer and California sheriff's deputy." USA Today. June 17, 2020. https://eu.usatoday. com/story/news/nation/2020/06/17/air-force-sergeant-alleged-ties-boogaloo-faces-murdercharges/3204094001/ (accessed on February 8, 2021).

DeCook, J. R. (2018). "Memes and Symbolic Violence: \#Proudboys and the Use of Memes for Propaganda and the Construction of Collective Identity." Learning, Media and Technology. 43(4): 485- 504.

Delgado, Henry Navarro. (2020). "Far-right 'boogaloo' movement is using Hawaiian shirts to hide its intentions." The Conversation. July 22, 2020. https://theconversation.com/far-rightboogaloo-movement-is-using-hawaiian-shirts-to-hide-its-intentions-142633 (accessed on February 1, 2021).

Evans, Robert \& Wilson, Jason. (2020). "The Boogaloo Movement Is Not What You Think." Bellingcat. May 27, 2020. https://www.bellingcat.com/news/2020/05/27/the-boogaloomovement-is-not-what-you-think/ (accessed on January 31, 2021).

Gidron, N. \& Hall, P. (2017). "The Politics of Social Status: Economic and Cultural Roots of the Populist Right." British Journal of Sociology. 68(1): 57-84.

Giglio, Mike. (2020). "A Pro-Trump Militant Group Has Recruited Thousands of Police, Soldiers, and Veterans." The Atlantic. November 2020. https://www.theatlantic.com/magazine/ archive/2020/11/right-wing-militias-civil-war/616473/ (accessed on February 1, 2021.)

Goldenberg, Alex \& Finkelstein, Joel. (2020). Contagion and Ideology Report: Cyber Swarming, Memetic Warfare and Viral Insurgency: How Domesti Militants Organize on Memes to Incite Violent Insurrection and Terror Against Government and Law Enforcement. The Network Contagion Research Institute. February 7, 2020. https://networkcontagion. us/reports/cyber-swarming-memetic-warfare-and-viral-insurgency-how-domestic-militants-organize-on-memes-to-incite-violent-insurrection-and-terror-against-government-and-law-enforcement/ (accessed on January 30, 2021).

Green, Jordan. (2020). "Homeland Security issues a startling internal alert after lockdown protester gets arrested for building pipe bombs." Raw Story. May 06, 2020. https://www. rawstory.com/2020/05/homeland-security-issues-a-startling-internal-alert-after-lockdown-protester-gets-arrested-for-building-pipe-bombs/ (accessed on January 30, 2021).

Hinton, Alexander. (2021). "US Capitol mob highlights 5 reasons not to underestimate farright extremists." The Conversation. January 8, 2021. https://theconversation.com/us-capitol-mob-highlights-5-reasons-not-to-underestimate-far-right-extremists-148610 (accessed 
on February 1, 2021).

Holthouse, D. (2006). "Several high profile racist extremists serve in the U.S. military." SPLC. August 11, 2006. https://www.splcenter.org/fighting-hate/intelligence-report/2006/several-high-profile-racist-extremists-serve-us-military (accessed on February 9, 2021).

Inglis, Jeff. (2021). "What is the 'boogaloo' and who are the rioters who stormed the Capitol? 5 essential reads." The Conversation. January 15, 2021. https://theconversation.com/ what-is-the-boogaloo-and-who-are-the-rioters-who-stormed-the-capitol-5-essentialreads-153337 (accessed on January 31, 2021).

Jones, Caleb. (2021). "Aloha Shirts on 'Boogaloos' Link Symbol of Peace to Violence." Associated Press. January 23, 2021. https://www.usnews.com/news/politics/articles/2021-01-23/aloha-shirts-on-boogaloos-link-symbol-of-peace-to-violence (accessed on January 30, 2021).

Komenda, Ed. (2020). "Men tied to 'boogaloo' movement conspired to spark protest violence in Las Vegas, feds say." USA Today. June 4, 2020. https://eu.usatoday.com/story/ news/nation/2020/06/04/boogaloo-movement-terrorism-related-charges-3-men-fedssay/3147563001/ (accessed on February 8, 2021).

Levinson, R. (2019). The fight in the right: It is time to tackle White supremacist terrorism globally. War on the Rocks.August 22, 2019. https://warontherocks.com/2019/08/the-fightin-the-right-it-is-time-to-tackle-white-supremacist-terrorism-globally/ (accessed on February 9,2021$)$.

Mac, Ryan \& Haskins, Caroline (2020). "Facebook Has Been Profiting From Boogaloo Ads Promoting Civil War And Unrest." BuzzFeed News. June 30, 2020. https://www.buzzfeednews.com/article/ryanmac/facebook-instagram-profit-boogaloo-ads (accessed on February 11, 2021).

Mathias, Christopher. (2020). "Amid The Pandemic, U.S. Militia Groups Plot 'The Boogaloo,' AKA Civil War, On Facebook." The Huffington Post. April 24, 2020. https://www.huffpost. com/entry/boogaloo-facebook-pages-coronavirus-militia-group-extremists_n_5ea3072bc5b6d376358eba98 (accessed on January 31, 2021).

Menn, Joseph. (2020). "Facebook limits spread of 'Boogaloo' groups amid protests." Reuters. June 6, 2020. https://www.reuters.com/article/us-facebook-boogaloo/facebook-movesto-limit-spread-of-boogaloo-groups-after-charges-idUSKBN23C011 (accessed on Feebruary 11, 2021).

Merkley, E. (2020). "Anti-Intellectualism, Populism, and Motivated Resistance to Expert Consensus." Public Opinion Quarterly. 84(1): 24-48.

Miller, Cassie. (2020). “The 'Boogaloo' Started as a Racist Meme." SPLC. June 5, 2020. https:// www.splcenter.org/hatewatch/2020/06/05/boogaloo-started-racist-meme (accessed on February 8, 2021).

Mudde, Cas. (2021). "Far-right extremism in the US is deadly serious. What will Biden do about it?" The Guardian.January 27, 2021. https://www.theguardian.com/commentisfree/2021/jan/27/far-right-extremism-us-terror-biden (accessed on January 30, 2021).

Newkirk II, Vann R. (2019). "The Racial Divide Is the Political Divide." The Atlantic. February 21, 2019. https://www.theatlantic.com/politics/archive/2019/02/racial-divisions-exist-amongwhites-blacks-and-hispanics/583267/ (accessed on January 30, 2021).)

Owen, Tess. (2020). "Far-Right Extremists Are Hoping to Turn the George Floyd Protests Into a New Civil War." Vice News. May 29, 2020. https://www.vice.com/en/article/pkyb9b/ far-right-extremists-are-hoping-to-turn-the-george-floyd-protests-into-a-new-civil-war 
(accessed on January 31, 2021).

Owen, Tess. (2020a). "The 'Boogaloo Bois' Are Bringing Their AR-15s and Civil War Ideology to the Lockdown Protests." Vice News. May 8, 2020. https:/www.vice.com/en/article/y3zmj5/ the-boogaloo-bois-are-bringing-their-ar-15s-and-civil-war-ideology-to-the-lockdown-protests (accessed on February 11, 2021).

Owen, Tess. (2020b). "Young Aspiring Boogaloo Bois Are Dancing With Guns on TikTok." Vice News. June 16, 2020. https://www.vice.com/en/article/xg8yjw/young-aspiring-boogaloo-bois-are-dancing-with-guns-on-tiktok (accessed on February 11, 2021).

Patches, Matt. (2014). “How 'Breakin' 2: Electric Boogaloo' Became a Movie and Then a Meme." Grantland. Dec. 22, 2014. https://grantland.com/hollywood-prospectus/howbreakin-2-electric-boogaloo-became-a-movie-and-then-a-meme/ (accessed on January 29, 2021).

Pemberton, Nathan Taylor. (2020). "What Do You Do When Extremism Comes for the Hawaiian Shirt?" The New York Times. June 29, 2020. https://www.nytimes.com/2020/06/29/ style/boogaloo-hawaiian-shirt.html?referringSource=articleShare (accessed on February 1 , 2021).

Perper, Rosie \& Sheth, Sonam. (2020). "3 self-proclaimed members of the far-right 'boogaloo' movement were arrested on domestic terrorism charges for trying to spark violence during protests." Business Insider. June 4, 2020. https://www.businessinsider.com/3-boogaloo-men-terror-charges-george-floyd-protest-riot-conspiracy-2020-6? $r=U S \& \mid R=T$ (accessed on February 1, 2021).

Pineda, Khrysgiana. (2020). "The boogaloo movement is gaining momentum. Who are the boogaloo 'bois' and what do they want?" USA Today. June 19, 2020. https://eu.usatoday. com/story/news/nation/2020/06/19/what-is-boogaloo-movement/3204899001/\#mainContentSection (accessed on February 8, 2021).

Ralston, Robert; Spindel, Jennifer \& Motta, Matt (2020). "When OK is Not OK: Public Concern About White Nationalism in the U.S. Military." Armed Forces and Society. March 21, 2020. 95327-. https://doi.org/10.1177/0095327X20918394

Rodriguez, Salvador. (2020). "Facebook removes accounts associated with 'boogaloo' movement amid ads boycott." CNBC. June 30, 2020. https://www.cnbc.com/2020/06/30/ facebook-removes-accounts-associated-with-boogaloo-movement.html (accessed on February 11, 2021).

Rotella, Sebastian. (2021). "Global Right-Wing Extremism Networks Are Growing. The U.S. Is Just Now Catching Up." ProPublica. January 22, 2021. https://www.propublica.org/article/ global-right-wing-extremism-networks-are-growing-the-u-s-is-just-now-catching-up (accessed on January 31, 2021).

Sands, Geneva. (2020). "White supremacy is 'most lethal threat' to the US." CNN. September 8, 2020. https://edition.cnn.com/2020/09/08/politics/white-supremacy-dhs-draft-assessment/index.html (accessed on February 1, 2021).

Sarna, Jonathan D. (2021). "A scholar of American anti-Semitism explains the hate symbols present during the US Capitol riot." The Conversation. January 8, 2021. https://theconversation.com/a-scholar-of-american-anti-semitism-explains-the-hate-symbols-present-duringthe-us-capitol-riot-152883 (accessed on January 31, 2021).

Shane, Leo III. (2017). "One in four troops sees white nationalism in the ranks." Military Times. October 23, 2017. https://www.militarytimes.com/news/pentagon-congress/2017/10/23/military-times-poll-one-in-four-troops-sees-white-nationalism-in-the- 
ranks/ (accessed on February 1, 2021).

Shane, L. III. (2019). "Lawmakers want closer tracking of white supremacy, Nazi sympathizers in the military." Military Times. September 12, 2019. https://www.militarytimes.com/ news/pentagon-congress/2019/09/12/lawmakers-want-closer-tracking-of-white-supremacy-nazi-sympathizers-in-the-military/ (accessed on February 1, 2021).

Shane, L. III. (2020). "Signs of white supremacy, extremism up again in poll of active-duty troops." Military Times. February 6, 2020. https://www.militarytimes.com/news/pentagon-congress/2020/02/06/signs-of-white-supremacy-extremism-up-again-in-poll-of-active-duty-troops/ (accessed on February 9, 2021).

Spindel, Jennifer; Motta, Matt \& Ralston, Robert. (2020). "Americans aren't worried about white nationalism in the military - because they don't know it's there." The Conversation. October 8, 2020. https://theconversation.com/americans-arent-worried-about-white-nationalism-in-the-military-because-they-dont-know-its-there-147341 (accessed on February 1, 2021).

Thompson, A.C. \& Fischer, Ford. (2021). "Members of Several Well-Known Hate Groups Identified at Capitol Riot." ProPublica. January 9, 2021. https://www.propublica.org/article/several-well-known-hate-groups-identified-at-capitol-riot (accessed on January 31, 2021).

Timberg, Craig; Dwoskin, Elizabeth; Mekhennet, Souad. (2020). "Men wearing Hawaiian shirts and carrying guns add a volatile new element to protests." The Washington Post. June 3, 2020. https://www.washingtonpost.com/technology/2020/06/03/white-men-wearings-hawaiian-shirts-carrying-guns-add-volatile-new-element-floyd-protests/ (accessed on February 10, 2021).

Tudela, Alex. (2016). "Aloha Shirts Leave Thrift Shops Behind." The New York Times. May 3, 2016. https://www.nytimes.com/interactive/2016/05/06/fashion/mens-style/aloha-Hawaiian-shirts.html (accessed on February 1, 2021).

Valasik, Matthew \& Reid, Shannon. (2020). "Why are white supremacists protesting the deaths of black people?" The Conversation. June 5, 2020. https://theconversation.com/ why-are-white-supremacists-protesting-the-deaths-of-black-people-140046 (accessed on January 31, 2021).

Weiner, Rebecca Ulam. (2020). "The Growing White Supremacist Menace." Foreign Affairs. June 23, 2020. https://www.foreignaffairs.com/articles/united-states/2020-06-23/growing-white-supremacist-menace (accessed on January 28, 2021).

Williams, Thomas Chatterton. (2017). "The French Origins of You Will Not Replace Us," The New Yorker. 27 November 2017, https://www.newyorker.com/magazine/2017/12/04/thefrench-origins-of-you-will-not-replace-us (accessed on February 8, 2021).

Woodward, Alex. (2020). "Why far-right protesters are wearing Hawaiian print." The Independent. May 30, 2020. https://www.independent.co.uk/news/world/americas/far-right-hawaiian-print-shirts-why-protesters-boogaloo-racist-a9539776.html (accessed on February 10, 2021).

Zadrozny, Brandy. (2020). "What is the 'boogaloo'? How online calls for a violent uprising are hitting the mainstream." NBC News. Feb. 19, 2020. https://www.nbcnews.com/ tech/social-media/what-boogaloo-how-online-calls-violent-uprising-are-getting-organized-n1138461 (accessed on January 29, 2021). 


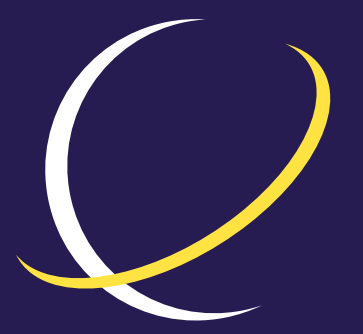

\section{ECPS \\ EUROPEAN CENTER for POPULISM STUDIES}

\section{ABOUT ECPS}

The European Center for Populism Studies (ECPS) is an independent, nonpartisan, nonprofit organization, based in Brussels, for research on and analysis of challenges posed by the resurgence of political populism. ECPS facilitates collaboration among networks of academic experts, practitioners, policymakers, media, and other stakeholders. ECPS offers a platform for the exchange of policy solutions on issues relating to rising populism and provides insights for policy-making and critical analysis to raise broader awareness and engagement through:

\section{Publications}

\section{Academic publications}

Policy reports

White papers

Commentaries

Podcasts and interviews with experts

Events, seminars, workshops, and conferences

\section{Research Programs}

Authoritarianism

Digital Populism

Economics

Environment \& Climate

Extremism \& Radicalisation

\section{Gender}

Human Rights

Foreign Policy

Leadership \& Persona

Migration

\section{ECPS Youth Program}

ECPS Academy 